\title{
A large skull of Ichthyosaurus (Reptilia: Ichthyosauria) from the Lower Sinemurian (Lower Jurassic) of Frick (NW Switzerland)
}

\author{
Michael W. Maisch ${ }^{1}$, Achim G. Reisdorf $^{2} *$, Rudolf Schlatter ${ }^{3} \&$ Andreas Wetzel $^{2}$
}

Key words: Ichthyosaurus communis, Ichthyosauria, skull, Lower Jurassic, Sinemurian, Switzerland

\begin{abstract}
An incomplete skull of an ichthyosaur attributed to Ichthyosaurus communis CONYBEARE 1822 is reported from the Lower Sinemurian calcarenites (upper part of the "Beggingen Member", previously "Arietenkalk", Semicostatum zone) of Frick (Canton Aargau, northern Switzerland). It is the first record of this genus and species in Switzerland, and the first definite record of the genus Ichthyosaurus from central Europe. This species was hitherto only known from Lower Hettangian to Lower Sinemurian deposits of England and Upper Sinemurian sediments of Belgium. The specimen represents a particularly large individual that considerably exceeds all known English representatives of this species in skull length, and is closest in size to the single specimen from Belgium. Unusual anatomical features include a strong coossification of the posterior skull-roof bones (probably a result of an old ontogenetic age) and a very elongate and deep excavatio internasalis. A short overview of substantial Swiss Mesozoic ichthyosaur finds is provided. The Jurassic record appears very patchy so far, but has been considerably improved thanks to recent discoveries.
\end{abstract}

\section{ZUSAMMENFASSUNG}

Der unvollständige Schädel eines Ichthyosauriers in Sedimenten des Unteren Sinemuriums (oberer Schichtenkomplex des "Beggingen-Members", bislang "Arietenkalk", semicostatum-Zone) von Frick, Kanton Aargau, Schweiz wird Ichthyosaurus communis CONYBEARE, 1822 zugeordnet. Diese Art war bisher nur aus dem Hettangium und Unteren Sinemurium von England und dem Oberen Sinemurium von Belgien bekannt. Es handelt sich um den ersten Nachweis dieses Taxons in der Schweiz und um den ersten definitiven Nachweis der Gattung Ichthyosaurus in Mitteleuropa überhaupt. Das Exemplar besitzt eine enorme Größe, die die aller englischen Exemplare weit übertrifft und dem einzigen Fund aus Belgien nahe kommt. Ungewöhnliche anatomische Merkmale sind unter anderem die starke Koossifikation der posterioren Schädeldachelemente, die vermutlich durch das hohe ontogenetische Alter des Tieres bedingt ist, sowie eine sehr lange und tiefe Excavatio internasalis. Ein kurzer Überblick der mesozoischen Ichthyosaurierfunde der Schweiz zeigt, dass insbesondere der jurassische Fossilbericht bislang sehr unvollständig ist, sich aber in den letzten Jahren durch neue Funde beträchtlich verbessert hat.

\section{Introduction}

The fossil record of ichthyosaurs in Switzerland is extensive, spanning most of the Mesozoic (Fig. 1). Numerous well-preserved skeletons of six different ichthyosaur genera have been discovered in the Middle Triassic fossillagerstätte of Monte San Giorgio (e.g. Sander 1989; Maisch \& Matzke 1997a, b, 2000a; Brinkmann 1998a, b, 2004; Maisch et al. 2006). From the Lower Muschelkalk of Canton Aargau, Huene (1916) and Callaway \& Massare (1989) discussed incomplete Middle Triassic (Anisian) specimens of mixosaurids and possible cymbospondylids. Maisch \& Matzke (2005) recently described a fragmentary skull specimen of the mixosaurid Phalarodon major from the Anisian of Aargau. The Lower Jurassic ichthyosaur finds from Switzerland were summarized by Maisch \& Reisdorf (2006a, b). Lower Jurassic ichthyosaurs include a complete skeleton of Stenopterygius longifrons from the Lower Toarcian of Teysachaux (Huene 1939), two incomplete skulls of Early Toarcian age from the Staffelegg, a complete skull from the Lower Toarcian of Asuel (e.g. Maisch \& Reisdorf 2006a, b), a complete skull and some associated postcrania of Leptonectes tenuirostris that was recently discovered in Upper Pliensbachian deposits at Unter Hauenstein (Maisch \& Reisdorf 2006a, b; Wetzel \& Reisdorf 2007), and a fragmentary indeterminate specimen was described by Weidmann (1981) from the Lower Toarcian at the Risseau de Chalevay near Montreux. In addition, numerous finds at various localities from the Rhaetian (Kuhn 1951; Callaway \& Massare 1989; Mettraux \& Mohr 1989; Furrer 1993; H. Furrer, pers. comm. 2006), Lower, Middle and Upper Jurassic (e.g. Peyer \& Koechlin 1934; den Brok et al. 2004) are still

\footnotetext{
${ }^{1}$ Institut und Museum für Geologie und Paläontologie, Sigwartstrasse 10, D-72076 Tübingen, Germany.

${ }^{2}$ Universität Basel Geologisch-Paläontologisches Institut, Bernoullistrasse 32, CH-4056 Basel, Switzerland.

${ }^{3}$ Naturkundemuseum Leipzig, Lortzingstrasse 3, D-04105 Leipzig, Germany.

*Corresponding author: A.G. Reisdorf. E-mail: achim.reisdorf@unibas.ch
} 


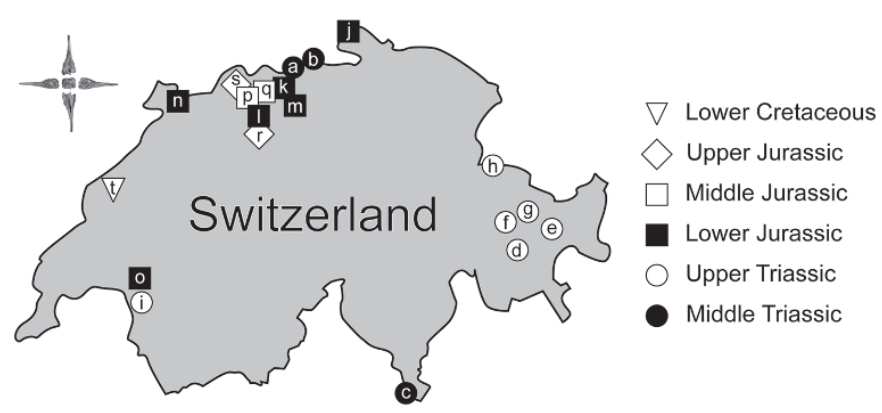

Fig. 1. Outstanding ichthyosaur finds from Switzerland. a, Laufenburg/AG (Huene 1916); b, Schwaderloch/AG (Moesch 1857; Maisch \& Matzke 2005); c, Monte San Giorgio/TI (e.g. Brinkmann 2004); d, Fil da Stidier (Bergün)/ GR (Furrer 1993); e, National Park region (Zernez)/GR (Furrer 1993); f, Ramoz (Arosa)/GR (Furrer 1993); g, Alplihorn (Davos)/GR (Furrer 1993); h, Schesaplana (Prättigau)/GR (Furrer 1993); i, Plan Falcon (Yvorne)/VD (Mettraux \& Mohr 1989; H. Furrer, pers. comm. 2006); j, Beggingen/SH (Früh 1962); k, Frick/AG (this paper); 1, Unter Hauenstein/SO (Maisch \& Reisdorf 2006 a,b); m, Staffelegg/AG (Maisch \& Reisdorf 2006 a, b); n, Asuel/JU (e.g. Maisch \& Reisdorf 2006a, b); o, Teysachaux/FR (e.g. Huene 1939) and Risseau de Chalevay/FR (Weidmann 1981); p, Buckten/BL (den Brok et al.2004); q, Ormalingen/BL (den Brok et al. 2004); r, Born (Ruppoldingen) S Olten/SO (Peyer \& Koechlin 1934; Naturmuseum Olten, [register numbers NMO 20141 to 20216]); Paläontologisches Institut und Museum der Universität Zürich [register number PIMUZ A/III 0863]; s, Grellingen/BL (Peyer \& Koechlin 1934); t, La Presta/NE (Ayer 2003).

undescribed. Ayer (2003) revealed a Cretaceous (Aptian) record was from La Presta (Canton de Neuchâtel). For the sake of completeness, we shall mention a not yet prepared rostrum of a still undetermined ichthyosaur, stored in the Sauriermuseum Frick since 2006, discovered between Sisseln und Rheinfelden (Canton Aargau) in sediments of the Rhine. Bones and teeth are embedded in concretions with high pyrite content of unknown stratigraphical origin (Lower Jurassic?).

In this paper, another important Swiss Jurassic ichthyosaur find is described. The reported skull, possible rib fragment and vertebrae (housed in the Sauriermuseum Frick), were found at Frick (Canton Aargau, northern Switzerland; Fig. 2), by Hans Hartmann in 1999. Despite these ichthyosaur remains were collected from scree, their stratigraphical position can be precisely dated to the Early Sinemurian (Early Jurassic). The reported

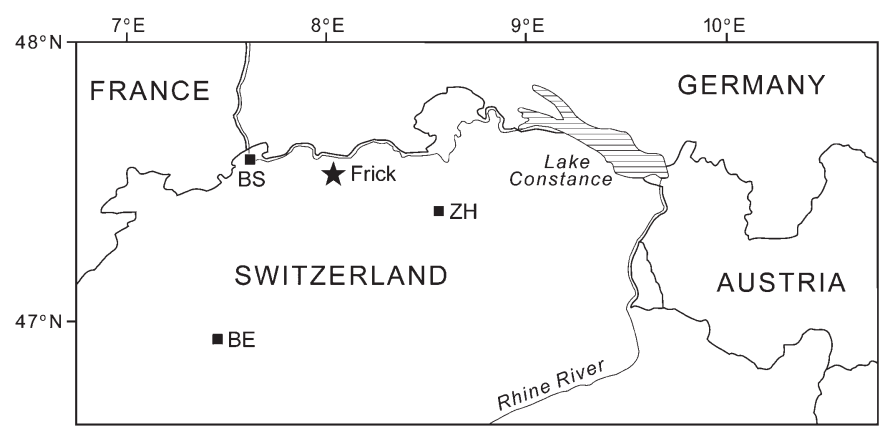

Fig. 2. Map of northern Switzerland, with the position of the fossiliferous locality of Frick (BE: Bern; BS: Basel; ZH: Zurich; modified after Wetzel \& Allia 2000). ichthyosaur is the first substantial specimen from this age in Switzerland, and one of the few diagnostic ichthyosaur specimens from the Sinemurian in continental Europe.

\section{Geological Setting}

The Lower Jurassic sediments of northern Switzerland are 25 to some 70 m thick (e.g. Braun 1920; Kelterborn 1944; Müller et al. 1984), that is considerably less than in the adjacent areas of Germany and France (e.g. Debrand-Passard 1984; Stoll-Steffan 1987; Bloos et al. 2005; Schmid et al. 2008). The Lower Jurassic deposits mainly consist of mud- and marlstones, calcarenites and limestones being intercalated. Frequently condensation, hiatuses and abrupt facies changes occur within a short distance (e.g. Erni 1910, 1926; Buser 1952; Jordan 1983).

The Frick section is subdivided according to the concept of the «Staffelegg Formation» (Fig. 3). The "Staffelegg Formation" is proposed to be used for the Early Jurassic sediments in northern Switzerland that have hitherto informally been summarized as the "Lias" (Jordan et al. 2008). Although the Swiss Committee for Stratigraphy agrees with the concept, the «Staffelegg Formation» has not be formally introduced yet while unpublished.

At Frick, in contrast to other localities in Switzerland, most of the Lower Jurassic is exposed in a clay pit (Meyer \& Furrer 1995). This section exposes sediments of the Lower Hettangian (Liasicus zone) to the Lower Toarcian (Falcifer zone) and is about $30 \mathrm{~m}$ thick (Schlatter 1975; W. Etter, pers. comm. 2006; own data). The Frick locality is famous for numerous finds of skeletal remains of prosauropod dinosaurs belonging to Plateosaurus and associated fauna (e.g. Galton 1986; Sander 1990, 1992; Hugi 2008) occurring in terrestrial Norian mudstones (= "Oberer Steinmergelkeuper" of the "Steinmergelkeuper Formation" sensu Etzold \& Schweizer 2005). The Triassic deposits are overlain by marine Lower Hettangian bituminous marls (Fig. 3: layers 1 to 9; "Schambelen Member", previously "Insektenmergel"; see Jordan et al. 2008).

Higher in the section, a ca. $4 \mathrm{~m}$ thick sequence is dominated by calcarenites; it is of Late Hettangian to Late Sinemurian age (Angulata zone to Obtusum zone) and represents the "Beggingen Member" (previously known as the "Angulatenschichten" and the "Arietenkalk"; see Jordan et al. 2008). The highly fossiliferous succession of layers 10 to 15, Late Hettangian to Early Sinemurian in age (Angulata zone to Semicostatum zone; Fig. 3), has revealed many disarticulated ichthyosaur remains (e.g. ribs and vertebrae; Sander 1990; Meyer \& Furrer 1995; Maisch \& Reisdorf 2006a, b; H. Hartmann, P. Vögtli, pers. comm. 2004).

For the age determination of the reported ichthyosaur remains, both the lithofacies and the mode of weathering of the layers 14 to 16 of the Frick section (= Semicostatum zone;Fig. 3) are of great significance. Layer 14 is about $50 \mathrm{~cm}$ thick and consists of quite resistant calcarenites rich in reworked phosphoritized moulds of invertebrates (Gryphaea, Plagiostoma, Cardinia, Oxytoma) and phosphatic pebbles (e.g. Buser 1952:

618 M.W. Maisch et al. 
Section Frick (Grube Gruhalde, Tonwerke Keller AG, Frick/ AG); coord.: 643.000 / 261.900
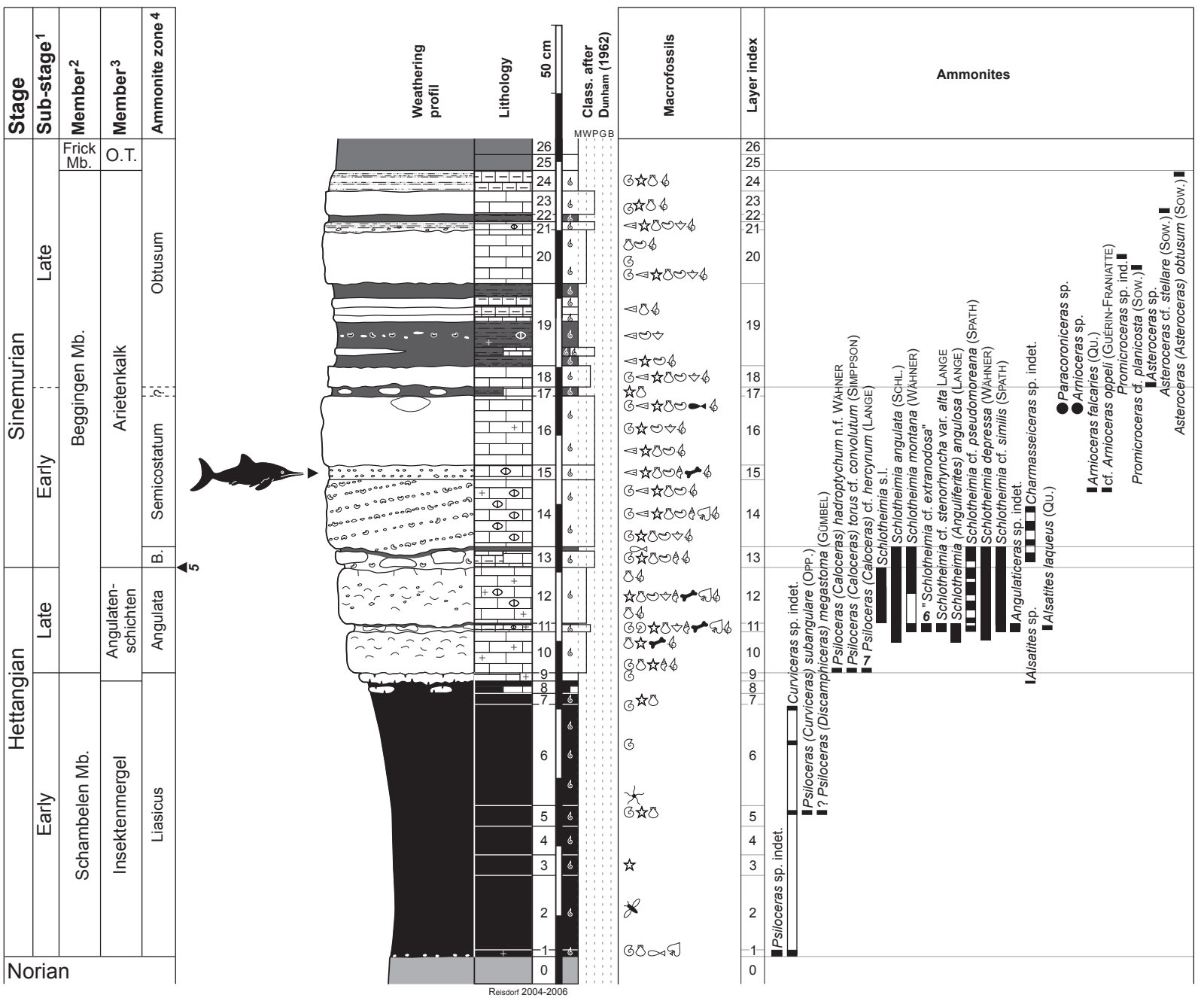

\begin{tabular}{|c|c|c|c|}
\hline \begin{tabular}{|l|l|}
1 \\
\end{tabular} & limestone & 6 & bioclasts \\
\hline 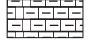 & marly limestone & G & ammonites \\
\hline$=$ & silty marlstone & (2) & nautilids \\
\hline & marlstone & 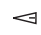 & belemnites \\
\hline & bituminous marly clays & $\hat{n}$ & crinoids \\
\hline (1) & phosphorite & * & brittle star \\
\hline+ & pyrite & 8 & pelecypods \\
\hline 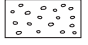 & phosphoritic nodules & $\ominus$ & gryphaeans \\
\hline \begin{tabular}{|l|}
$\infty$ \\
1
\end{tabular} & $\begin{array}{l}\text { bioturbated nodule/ } \\
\text { surface }\end{array}$ & $\diamond$ & brachiopods \\
\hline 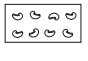 & bed rich in gryphaeans & $\Leftrightarrow$ & gastropods \\
\hline
\end{tabular}

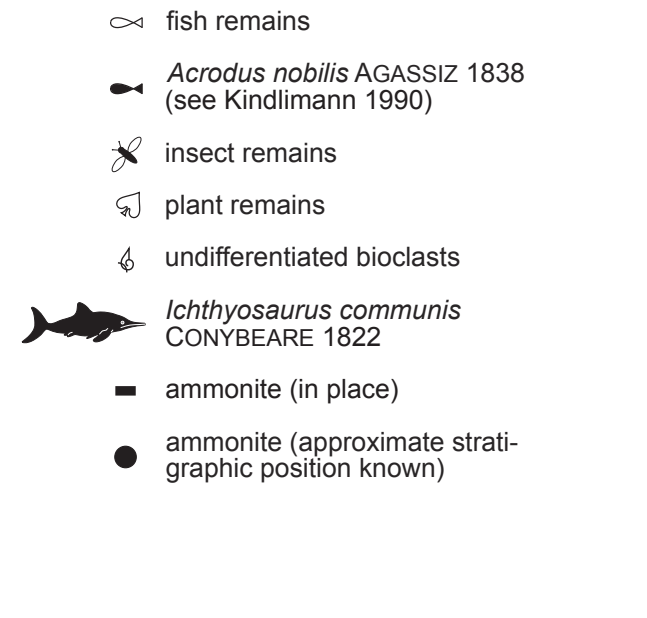

Fig. 3. Detailed section of the Lower Hettangian to Upper Sinemurian strata (Liasicus to Obtusum zone) at Frick. Abbreviations: O.T., Obtusus-Ton; B., Bucklandi zone; ?, uncertain biostratigraphical affiliation. 1: sub-stage sensu Urlichs (1977); 2, Member after Reisdorf et al. in Jordan et al. (2008); 3, Member sensu Müller et al. (1984); 4, ammonite zone sensu Dean et al. (1961) and sensu Bloos (1979); 5, position of the boundary between Upper Hettangian and Lower Sinemurian sensu Hoffmann (1934), Walliser (1956a, b) and Schlatter (1975); 6, "Schlotheimia cf. extranodosa" (Schlatter 1975: 86); 7, revision of "Psiloceras (Caloceras) cf. johnstoni (Sow.)" (Schlatter 1975: 76). 
section 16; Gsell 1968; Schlatter 1975; Meyer \& Furrer 1995). The 10 to $20 \mathrm{~cm}$ thick layer 15 contains apparently slightly less carbonate and less reworked phosphoritic pebbles and macrofossils, but exhibits a similar lithofacies (Peters 1964). It is less resistant against erosion as the layers 14 and 16 . Layer 16 is about $50 \mathrm{~cm}$ thick and contains less macrofossils than the underlying layers, although it is lithologically similar. Although the reported specimens were retrieved from scree and were not associated with datable ammonites, their stratigraphical position has been reconstructed with certainty by a detailed bio- and lithostratigraphical analysis, and the presence of the characteristic phosphoritic facies and the erosion behaviour of layer 15 (Fig. 3). The biostratigraphical age of the host stratum has been identified as Semicostatum zone (Early Sinemurian).

\section{Systematic Palaeontology \\ Order Ichthyosauria DE BLAINVILLE 1835 \\ Family Ichthyosauridae BONAPARTE 1841 \\ Genus Ichthyosaurus DE LA BECHE \& CONYBEARE 1821 \\ Type species Ichthyosaurus communis CONYBEARE 1822}

\section{Ichthyosaurus communis CONYBEARE 1822}

(Figs. 4-7)

Material. - An incomplete skull (SMF 46), a possible rib fragment (on the slab of SMF 46), two complete and a third fragmentary vertebra (SMF 66). The specimens are housed in the Sauriermuseum Frick (Switzerland).

Emended diagnosis. - Large species, skull reaching more than $600 \mathrm{~mm}$ in length, robust and moderately long snout (ratio length of snout to length of jaw $0.57-0.69$ ), moderately large orbit (ratio of orbit length to jaw length $0.20-0.28$, but usually $<0.25$ ), less than 20 maxillary teeth, robust and curved teeth, with blunt tips, roots never abruptly expanding, lacrimal with enormous anterior extension below premaxilla, jugal with rounded cross-section, quadratojugal moderately short dorsoventrally, reaching down distinctly below two thirds the orbital height, quadrate ascending plate robust, not a thin lamina as in Ichthyosaurus intermedius (modified from McGowan 1974 and Maisch \& Matzke 2000a).

Description. - The skull of Ichthyosaurus communis has been described in detail by various authors (notably by Sollas 1916; McGowan 1973; with additions by Godefroit 1996; Maisch \& Matzke 2000b). Therefore, the present description focuses on the important and unusual features.

The specimen is still embedded in the rock, in a slab ca. $700 \times 500 \mathrm{~mm}$ in size (Fig. 4). Most of the snout is missing, but the narial region is preserved on the right side (Fig. 5). The dorsal and part of the right as well as little of the left lateral surfaces of the skull have been prepared (Figs. 4-6). Some additional skull elements and several teeth, which have detached from the major part of the skull, are spread over the slab and have been partially prepared as well (Fig. 4). Except for a possible rib fragment there are no remains of the postcranium. Two complete and a third fragmentary vertebra were found
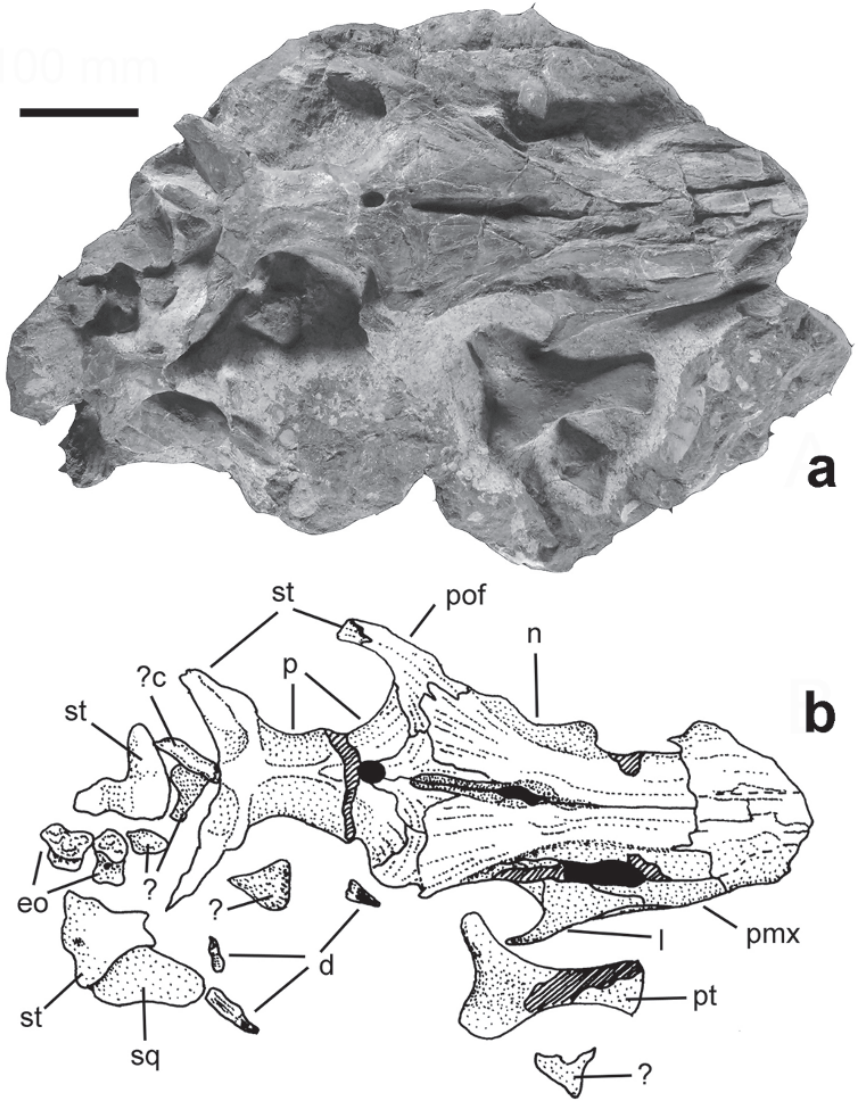

Fig. 4. Incomplete skull of Ichthyosaurus communis CONYBEARE 1822 (SMF 46), in dorsal view. a) Photograph. b) Interpretative sketch. Abbreviations: ?c, possible rib; d, teeth; eo, exoccipital; 1, lacrimal; n, nasal; p, parietal; pmx, premaxilla; pof, postfrontal; pt, pterygoid; sq, squamosal; st, supratemporal. Scale bar: $100 \mathrm{~mm}$

dismembered close to the cranium (Fig. 7). Their size fits to that of the skull. They very likely derive from the same specimen and are, therefore, briefly described and figured here.

A major portion of the cranium has undergone considerable dorsoventral distortion. Nevertheless, it retains much of its three-dimensional structure. The preorbital portion of the skull has suffered most from both distortion and weathering, and sutures are in part hard to follow. The orbital and postorbital portions are, in contrast, very well preserved.

Parts of the posterior portions of both premaxillaries are present, but strongly damaged. On the right side, the premaxilla forms a straight suture with the nasal anterior to the naris and also forms the anterior border of the naris (Fig. 5). The processus supranarialis is broken off, but it is still well preserved and extends along the ventral margin of the naris for about $40 \mathrm{~mm}$, almost reaching the posterior margin of that opening. It is ventrally sutured to the lacrimal for its entire length. There a part of the premaxilla is broken exposing the underlying lacrimal, which extends anteriorly almost to the level of the anterior narial margin (Fig. 5). Ventrally, both lacrimal and premaxilla are

620 M.W. Maisch et al. 
sutured to the maxilla anterior to and below the external naris. Only the dorsalmost portion of the maxilla is exposed. The postnarial portion of the lacrimal is strongly expanded dorsally and posteroventrally, where it forms a process about $40 \mathrm{~mm}$ in length (not completely prepared posteriorly) that took part in the suborbital arch and ventral margin of the orbit. Dorsal to the origin of this posteroventral process, the lacrimal is posteriorly covered by the descending lamina of the prefrontal, with which it forms a straight, anterodorsally ascending suture. Dorsally, a convex contact with the nasal is established. At the junction of nasal, prefrontal and lacrimal a massive crack traverses the bones and masks the sutures.

The prefrontal is only little exposed along the anterodorsal and dorsal orbital margin (Figs. 4-6). Its descending flange is extensive and forms most of the anterior orbital margin. Its exposure on the skull roof is only $15 \mathrm{~mm}$ wide at maximum. A deep trough is formed along the nasal-prefrontal suture (Fig. 5). In part it might be a preservational artifact caused by dorsoventral compression.

The postfrontal is incomplete on the right side, but complete on the left side (Figs. 4 \& 6). It forms the posterior half of the dorsal orbital margin. The contact with the prefrontal is unclear, due to incomplete preservation. It is overlapped by the nasal anteriorly. As the posteriormost portions of both nasals are slightly damaged, parts of the underlying postfron-

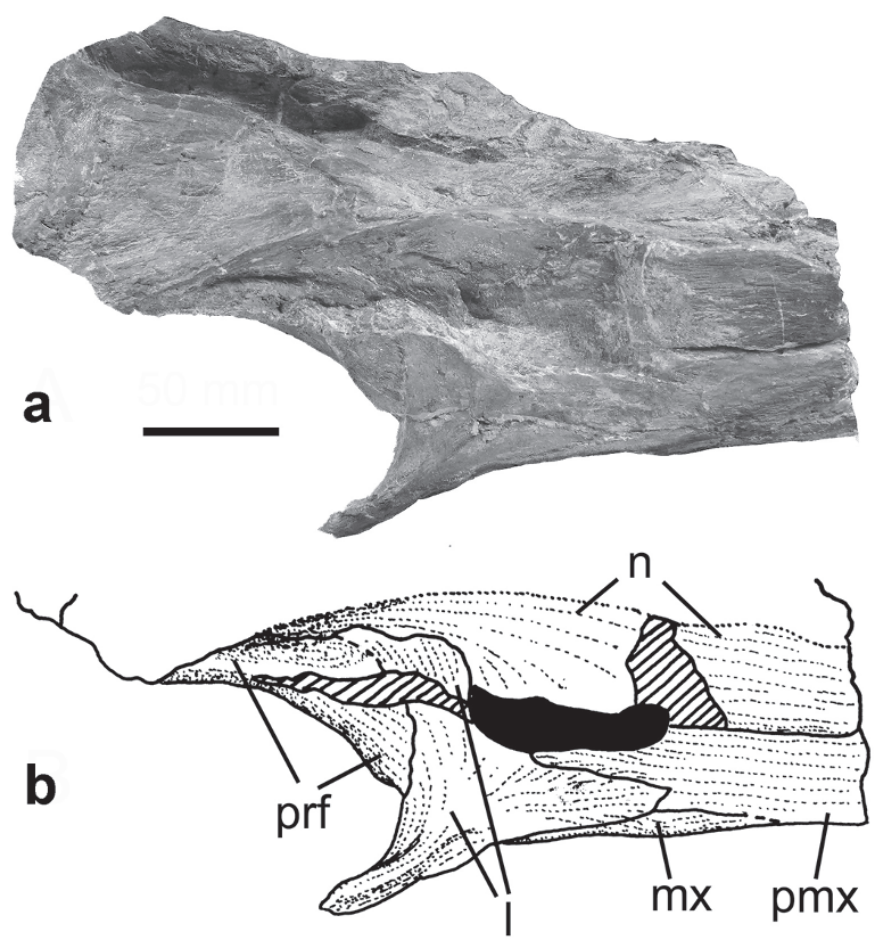

Fig. 5. Right circumnarial region of the skull of Ichthyosaurus communis Conybeare 1822 (SMF 46). a) Photograph. b) Interpretative sketch. Abbreviations: 1, lacrimal; mx, maxilla; n, nasal; pmx, premaxilla; prf, prefrontal. Scale bar: $50 \mathrm{~mm}$. tal have been exposed in places. The suture between nasal and postfrontal is strongly serrate in its lateral half, but more or less gently concave medially. It ends about $55 \mathrm{~mm}$ medial to the orbital margin on the left side. At this point, the postfrontal forms a short, straight suture with the frontal. This suture shows no major overlap between the bones on either side.

Posteriorly the postfrontal is sutured to the parietal. The suture extends from a point close to the anterolateral corner of the temporal fenestra in an anteromedial direction for a length of about $45 \mathrm{~mm}$ before the parietal contacts the frontal. The amount of overlap between postfrontal and parietal again appears to have been limited. However, the surfaces of the bones clearly indicate that a posterior sheet of the postfrontal that overlapped the anteriormost portion of the parietal was originally present. The portion of the postfrontal situated between the nasal anteriorly, parietal posteriorly and frontal medially is only $15 \mathrm{~mm}$ wide medially. The posterolateral portion of the postfrontal takes part in the formation of the anterolateral margin of the temporal fenestra. That margin is formed by the postfrontal for a length of about $35 \mathrm{~mm}$ on the left side. Further posteriorly, the postfrontal is replaced by the anterior process of the supratemporal. The anteriormost $25 \mathrm{~mm}$ of this process are still attached to the postfrontal on the left side (Fig. 4). The two bones form a very tight, almost closed suture. Whether there was a medial lamella of the postfrontal covering the inner wall of the supratemporal anteriorly is uncertain, due to incomplete preparation.

The nasals are extensive elements. They form most of the dorsal skull roof up to the level of half orbital length (the length of the orbit can be assumed to have been about $200 \mathrm{~mm}$ from comparison to other, more complete specimens). Special attention must be given to the expression of the excavatio internasalis in the present specimen, which is, in fact, a conspicuous, deep, trough-like structure that extends for a considerable length between the nasals and frontals and is, therefore, termed the fossa nasofrontalis here (Figs. 4 \& 6). It must be noted that some of the structures descibed might be slightly overexaggerated due to dorsoventral compression and a resulting spreading of the nasals. Most of the structures, including the internasal foramen and the deep fossa that extends almost to the foramen parietale which follows it posteriorly are, however, definitely genuine.

From the level of half the length of the external naris, of which the nasal forms the dorsal margin, the fossa nasofrontalis starts as a narrow groove between both nasals. Anteriorly, it is only $2 \mathrm{~mm}$ wide and very shallow, but at the level of the posterior margin of the naris it has expanded to a width of $5 \mathrm{~mm}$ and has deepened considerably. Shortly behind the level of the anterior orbital margin, the groove expands again to a width of now $10 \mathrm{~mm}$. In fact the two nasals loose contact and enclose a foramen internasale about $30 \mathrm{~mm}$ in length and $10 \mathrm{~mm}$ in width. The lateral margins of the foramen seem to be intact, so there is no evidence that it is an artificial structure. The lateral walls of the fossa nasofrontalis are still formed by the nasals, which bulge considerably dorsally on both sides, so that the midline 
groove and foramen are now situated in a deep trough, a true fossa, about $25 \mathrm{~mm}$ wide and almost $20 \mathrm{~mm}$ deep.

The fossa continues up to a point only $20 \mathrm{~mm}$ anterior to the foramen parietale. Its posterior border is formed by the frontals, which also take part in the formation of its lateral walls for a considerable distance further anteriorly. The fossa has narrowed to a width of only about $14 \mathrm{~mm}$ at its posterior end. In its depth, the midline groove is still present. A small foramen pierces the frontal in the posterior wall of the fossa. It is possibly an artifact. If not, it could indicate that the fossa nasofrontalis communicated with the canalis parietalis.

Lateral to the fossa nasofrontalis, the nasals are flat plates of bones that fan out posteriorly to establish contact with the postfrontal and frontal (Figs. 4-6). Their flat dorsal surface is probably in part a result of compression. The suture with the postfrontal was described above, that with the frontal is strongly asymmetrical (Figs. 4 \& 6). On the left side, it is almost straight and directed medially and slightly anteriorly for about $20 \mathrm{~mm}$ then the suture turns almost straight anteriorly. A long process of the frontal extends for about $55 \mathrm{~mm}$ forwards and excludes the nasal from the lateral wall of the fossa nasofrontalis. On the right side, the contact between the nasal and frontal is generally similar, except that the nasal largely overlaps the anterior process of the frontal and covers it almost completely after a distance of only $20 \mathrm{~mm}$. Of course the possibility exists that this apparent asymmetry is caused by part of the posteromedial portion of the left nasal having broken off, exposing the underlying frontal.

Posterior to the contact with the nasal, the frontal forms a short suture with the postfrontal, as described above. At this point, the bone extends furthest laterally. Posterior to that point, the parietal-frontal suture runs medially and slightly posteriorly, so that the frontal becomes rapidly narrower towards the foramen parietale. At the level of the anterior margin of the foramen parietale, the two frontals are only $25 \mathrm{~mm}$ wide, whereas they are $75 \mathrm{~mm}$ in width at the contact with the postfrontals. The foramen parietale is bordered by the frontals anteriorly and also laterally, as narrow processes of the bone extend along the lateral margin of the aperture almost to its posterior end (Fig. 6). Only the posterior margin of the foramen proper is formed by the parietals.

The parietals are massive bones, which form most of the anterior, the entire medial and the medial posterior margins of the extensive temporal fenstrae (Figs. 4 \& 6). The left temporal fenestra has a length of about $145 \mathrm{~mm}$. The right one is only $115 \mathrm{~mm}$ in length. These discrepancies are probably due to distortion. The original length of the temporal fenestra was probably inbetween these two measurements, i.e. 120 to $130 \mathrm{~mm}$.

Posterior to the foramen parietale, the two parietals join to form a low, but massive crista sagittalis, which is $15 \mathrm{~mm}$ high at maximum and extends for a length of $60 \mathrm{~mm}$. The lateral surfaces of the parietals are smooth except for marked ridges, which extend dorsoventrally and take a posteriorly convex course. They are situated about $15 \mathrm{~mm}$ behind the foramen parietale on both sides. As the parietals are traversed by a massive crack, almost $15 \mathrm{~mm}$ in width, at this level, the possibility exists that these ridges are a result of distortion. The posterior portion of the skull roof appears to have been pushed dorsally with respect to the anterior part.

The descending flange of the parietal is an extensive, laterally convex plate of bone. The ventral contact to the epipterygoid is not exposed on either side. Posterolaterally, each parietal is expanded into an occipital flange with a slightly concave posterior surface and a reinforced dorsal margin. The midline between the occipital flanges also bears a wide and low bony ridge (Fig. 4). All these ridges, the dorsal ridges and sagittal ridge of the occipital flanges and the crista sagittalis are connected by a roughened, cruciform platform of bone about $30 \mathrm{~mm}$ long and $25 \mathrm{~mm}$ wide.

It is remarkable that there is neither an indication of a sagittal parietal suture, nor is it possible to determine the suture between the occipital flanges of the parietal and the occipital ramus of the supratemporal on either side (Figs. 4 \& 6). From comparison with other specimens it is clear, that part of the supratemporal is still attached to the parietal in the preserved parts of the posterior margin of the temporal fenestra on either side. It therefore seems, that the posteriormost components of the skull roof of the specimen must have been synostotically connected and the sutures between the bones have become completely obliterated. This can probably be regarded as an indication of a very old individual age of the specimen.

The supratemporals are largely detached from the major part of the skull. Only the anteriormost portion of the anterior ramus of the left supratemporal and part of the occipital rami of both bones are still attached to the postfrontal and parietals respectively (Fig. 4). That the bone should break rather than detach along the sutures from the rest of the skull strengthens the case for strong coossification made above.

A large plate of bone, that is situated posterolateral to the right half of the skull, shows a natural margin of a skull opening and a triradiate structure. It clearly represents most of the broken and rotated right supratemporal (Fig. 4). It is remarkable that the occipital ramus is really completely broken over a large area of bone.

A second, plate-like element lies further laterally adjacent to the right supratemporal, by which it is partially covered (Fig. 4). It appears to have been a large but thin plate of approximately triangular outline. It appears, therefore, most plausible that it is the right squamosal that has completely detached from the rest of the skull, a common phenomenon in post-Triassic ichthyosaurs (Maisch 1998).

A third, large element that has lost most of its original margins lies directly posterior to the skull. It probably represents the detached part of the left supratemporal (Fig. 4).

Between the supratemporals, both exoccipitals are partially exposed (Fig. 4). The left exoccipital, situated further posteriorly, shows its medial, the right one its posterior surface. Both surfaces seem to be pierced by one large foramen each for transmission of the nervus hypoglossus. The bones otherwise confirm well to the detailed description of McGowan (1973). 
Adjacent to the right orbit a partial right pterygoid is exposed in ventral view (Fig. 4). The bone is incomplete anteriorly and the remaining parts are heavily restored. It shows no noteworthy features.

Several indeterminate bone fragments are in addition spread over the slab. Apart from those, there are also three teeth (Fig. 4), which have all suffered heavy damage, but which nevertheless provide some interesting and important data. The largest tooth is $48 \mathrm{~mm}$ in apicobasal length. The root is strongly damaged, but apparently had a somewhat rectangular rather than rounded cross-section. The crown is about $16 \mathrm{~mm}$ long and $7 \mathrm{~mm}$ wide mesiodistally. It is markedly recurved. The crown is covered with strong, widely spaced apicobasal ridges (about 2 per mm close to the base); its tip is blunt.

The two other teeth are less well preserved. One is significantly smaller, only about $28 \mathrm{~mm}$ in total length. The second one is incomplete, most of the root is missing. It was apparently even larger than the best preserved large tooth. None of the teeth shows any indication of carinae. What is visible of the crowns corresponds to the description above.

Together with the skull, but not in direct association with it, a slab of rock containing two complete ichthyosaur vertebral centra and a fragment of a third one was found (Fig. 7). Although it is not beyond doubt that both specimens belong to the same individual, the probability seems high, particularly with regard to the general rarity of associated ichthyosaur remains in the "Beggingen Member".

The largest and best preserved centrum has a dorsoventral sagittal height of $81 \mathrm{~mm}$. The anterior articulation surface is $86 \mathrm{~mm}$ wide, the dorsal sagittal length is $39 \mathrm{~mm}$. The vertebra apparently represents a posterior thoracal or anterior caudal centrum, as the single rib articulation facet, visible on the left side, is situated well below half the height of the centrum. Whether the articulation was double, as expectable for a thoracal vertebra, or single, as in a caudal, cannot be decided, as both ventrolateral surfaces of the centrum are still covered by matrix. The ventral surface is also inaccessible, so it remains unclear whether there were haemapophyseal facets, although it appears unlikely from what is visible. The anterior articulatory surface is deeply and evenly concave. The width of the neural canal and the facets for the neural arch is $37 \mathrm{~mm}$ anteriorly.

The second vertebral centrum is of almost equal size, being $82 \mathrm{~mm}$ in height and $85 \mathrm{~mm}$ in width. Its ventral surface is partially exposed and shows no indication of haemapophyseal facets. The lateral surfaces are, unfortunately either matrix-covered or so heavily damaged as to obscure the rib articulation completely. The third centrum is so fragmentary that it is not further determinable.

Comparison. - The lower Lower Jurassic of Europe has yielded the remains of four ichthyosaur genera so far (Maisch \& Matzke 2000a), the temnodontosaurid Temnodontosaurus, the ichthyosaurid Ichthyosaurus and the leptonectids Leptonectes and Eurhinosaurus. It can be concluded by closer comparison that the newly descriped specimen does not belong

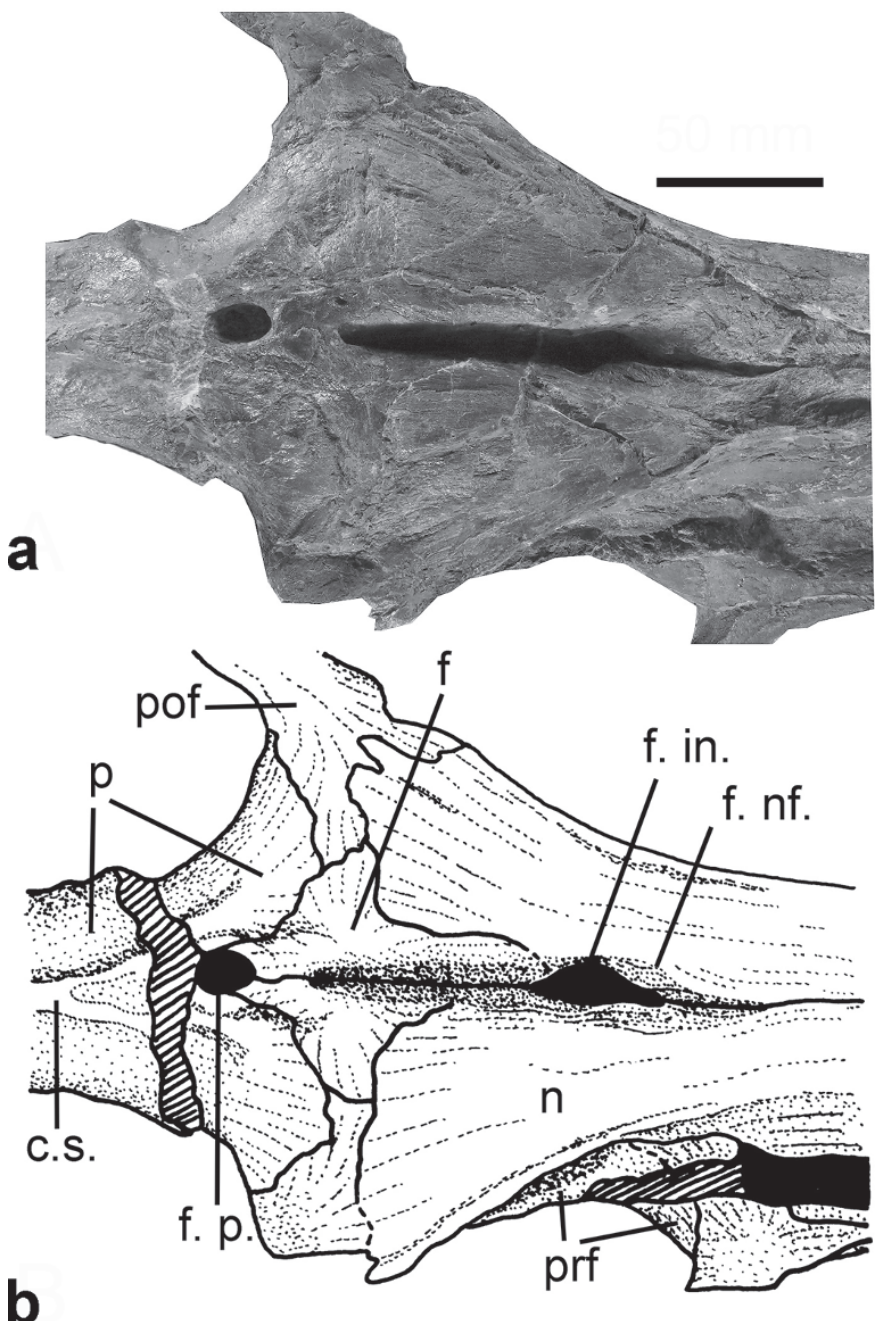

Fig. 6. Skull roof of Ichthyosaurus communis CONYBEARE 1822 (SMF 46). a) Photograph. b) Interpretative sketch. Abbreviations: c. s., crista sagittalis; f, frontal; f. in., foramen internasale; f. nf., fossa nasofrontalis; f. p., foramen parietale; n, nasal; p, parietal; pof, postfrontal; prf, prefrontal. Scale bar: $50 \mathrm{~mm}$.

to the following genera. (1) The leptonectids, Leptonectes and Eurhinosaurus, are readily distinguished from the specimen by their small temporal fenestrae, gracile snouts and long, slender and unornamented teeth. (2) The members of the genus Temnodontosaurus are usually much larger than the present specimen. Nevertheless, the possibility exists that it represents a juvenile. This is strongly contradicted not only by the high degree of coossification of the skull bones indicated above, which demonstrates that the individual was probably very old, but also by morphological features. The temnodontosaurids have a long postorbital skull segment, even as juveniles. In the present specimen, the postorbital skull segment was certainly less than half as long as the orbital diameter. The teeth of temnodontosaurids, particularly of the early Early Jurassic species T. platyodon, bear marked carinae. No indication of them is found in the present specimen. The nasals of Temnodontosaurus extend far above the orbits to meet the parietals. They are clearly sepa- 
rated from the parietals by the postfrontals and frontals in the present specimen.

The genus Ichthyosaurus is represented by three (McGowan 1974) or four (Maisch 1997; Godefroit 1996; Maisch \& Matzke 2000a) species from the early Early Jurassic. Of these, only one, Ichthyosaurus communis, is known to reach a skull length in excess of $500 \mathrm{~mm}$. The present specimen shows numerous diagnostic characters of $I$. communis, as the species was most recently diagnosed by Maisch \& Matzke (2000a, b): it is large, reaching more than $600 \mathrm{~mm}$ in skull length, it has a moderately large orbit (as contrasted to the very large orbits of $I$. breviceps and $I$. conybeari; see McGowan [1974] for more details), its teeth are robust and curved, with blunt tips, their roots are never abruptly expanding (in contrast to I. intermedius; see Maisch [1997]), they have in part a somewhat rectangular cross-section (Godefroit 1996) and the lacrimal has an enormous anterior extension below the premaxilla (see Maisch \& Matzke 2000b).

Some other diagnostic features, such as the morphology of the jugal, quadratojugal and the number of maxillary teeth can, of course, not be assessed in the present specimen due to incomplete preservation. Nevertheless, it is evident that of all the described early Early Jurassic ichthyosaurs, it can only be referred to Ichthyosaurus communis. Most of the features described above correspond well to what is known about that species. Some unusual features of the specimen do not preclude identification as I. communis. Although a foramen internasale is not ubiquitously present in that taxon (Maisch \& Matzke 2000b), it is characteristic of some individuals (McGowan 1973), including the Swiss specimen. An extensive fossa nasofrontalis is known to occur in several English specimens of I. communis (A. Hungerbühler, pers. comm.). The coossification of the parietals and supratemporals, although unusual, is probably best explained as a result of very old age. This is well in accordance with the very large size of the specimen, and therefore not considered to be of taxonomic significance. The strong crista sagittalis of the parietals is a bit unusual, but lower sagittal crests are usually found in the smaller English specimens (McGowan 1973; pers. obs.) and can become quite conspicuous in the larger ones, such as the skull sectioned by Sollas (1916). There is apparently no major overlap between the frontal and postfrontal, such as in the specimen described by Maisch \& Matzke (2000b). This is certainly in part a result of preservation. Nevertheless, the overlap is seemingly not that considerable in large specimens, as again demonstrated, for instance, by Sollas (1916).

The only discrepancy between the Swiss specimen and all those hitherto published from the English lower Lower Jurassic lies in its considerably larger size. The maximum mandibular length of the English representatives of Ichthyosaurus communis is, according to McGowan (1974), who studied and measured 39 determinable specimens, $600 \mathrm{~mm}$. The Swiss specimen must have had a mandibular length of at least $900 \mathrm{~mm}$, and this is a conservative estimate. It is, thus, at least 1.5 times larger than any of the English specimens.

However, such a large size is not unique for Ichthyosaurus communis, as was convincingly demonstrated by Godefroit
(1996). He described an incomplete skull from the Upper Sinemurian (Oxynotum zone) of Bonnert in Belgium. This specimen is of particular interest, as it is not only the stratigraphically youngest definite record of the genus Ichthyosaurus so far, but it is also geographically closest to the new find from Switzerland. Furthermore, it is the largest skull of Ichthyosaurus hitherto described. From Godefroit's (1996) thorough description and comparison it is evident, that the attribution of the specimen to I. communis is, at our current limited state of knowledge on these early Early Jurassic forms, justified. Although the skull is not complete, Godefroit (1996: 83) clearly indicates that the specimen must have surpassed the $600 \mathrm{~mm}$ mandibular length given as maximum value for the English specimens. In fact, it appears very plausible that his specimen was not smaller than the Swiss individual. An isolated parietal figured by Godefroit (1996) has a length of about 240-250 mm. The same bone in the Swiss specimen is only about $170 \mathrm{~mm}$ in length. The right postfrontal of Godefroit's (1996) specimen exceeds $140 \mathrm{~mm}$ in length, whereas it is only about $110 \mathrm{~mm}$ long in the Swiss specimen.

It is therefore clear, that the Belgian Ichthyosaurus communis described by Godefroit (1996) was at least as large, and very probably considerably larger, than the new specimen from Frick. As no such large Ichthyosaurus specimens have ever been found in England, the question arises, whether a taxonomic distinction existed between the English I. communis and the specimens attributed to that species from the Sinemurian of Europe. As far as morphological comparisons are possible, there are at present, however, no characters apart of larger size that could serve to separate either the Swiss or the Belgian specimens from I. communis. This might be due to the incomplete knowledge of the osteology of these forms, which are only known from part of the skull. For the time being, with the limited data presently at hand, it is at any rate best to take a conservative course instead of erecting a new taxon based on incomplete remains. We therefore refer the Frick specimen formally to Ichthyosaurus communis CONYBEARE 1822.

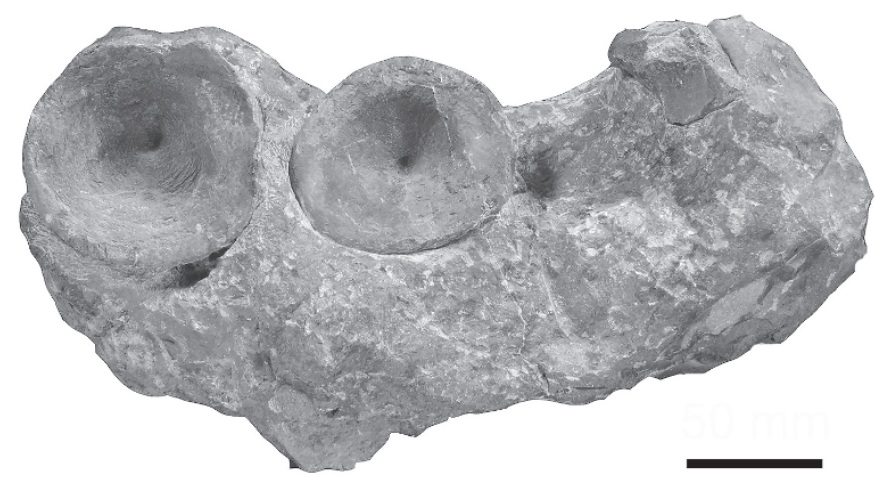

Fig. 7. Two complete vertebral centra, probably posterior thoracals, and a fragmentary third centrum extracted from the Lower Sinemurian ("Beggingen Member") at Frick (SMF 66). They might be associated with the reported skull (SMF 46). Scale bar: $50 \mathrm{~mm}$. 


\section{Discussion and conclusions}

The discovery of Ichthyosaurus communis in the "Beggingen Member" of Frick is an important addition to the marine reptile fauna of the Early Sinemurian of Central Europe. Very few diagnostic marine reptile specimens have ever been discovered from these strata. There is no generically or specifically diagnostic plesiosaur material known, although an incomplete skeleton, including a partial skull, from the uppermost Lower Sinemurian ("Alphaölschiefer") was found in the 1990ies at Balingen-Engstlatt (SW Germany). This specimen (housed in the Staatliches Museum für Naturkunde, Stuttgart) remains undescribed.

The "Alphaölschiefer", a bituminous shale of the uppermost Lower Sinemurian (Urlichs 1977; Klein 1986), has yielded a number of ichthyosaur remains that have been reviewed by Maisch (1999). Leptonectes tenuirostris, which was already indicated by Huene (1922) is recorded by an ill-preserved but almost complete skull from Dusslingen (SW Germany). The occurrence of Temnodontosaurus cf. platyodon was indicated by a partial postcranial skeleton (Maisch 1999), also from Dusslingen. Other ichthyosaur remains from the "Alphaölschiefer" proved undiagnostic as to species or even genus. Temnodontosaurus platyodon was so far also the only ichthyosaur species definitely recorded from the typical "Arietenkalk-facies" of SW Germany. The record of this taxon is based on a well-preserved partial premaxilla that was described in detail by Berckhemer (1938).

Some fragmentary material including teeth and a basisphenoid, that is very suggestive of Ichthyosaurus, was described by Reiff (1935) from the uppermost Sinemurian of Malsch (SW Germany). An isolated dentary, from the Lower Hettangian (Planorbis zone), was noted as possibly belonging to Ichthyosaurus by Maisch (1999). Nevertheless, substantial and fully diagnostic, associated skeletal remains of this genus, which is the most common ichthyosaur by far in the lower Lower Jurassic of England, were hitherto entirely missing from Central Europe.

The new specimen from Frick closes this gap. Three of the most common English lower Lower Jurassic ichthyosaurs, Ichthyosaurus communis, Leptonectes tenuirostris and Temnodontosaurus platyodon are now definitely known from the Lower Sinemurian of Central Europe. These three species have also been reported from Lower Sinemurian to Lower Pliensbachian strata of Belgium (Godefroit 1992, 1993, 1996), Leptonectes tenuirostris has also been recorded from the Upper Pliensbachian of Switzerland (Maisch \& Reisdorf 2006a, b). Therefore the lower Lower Jurassic (and probably also the little known middle Lower Jurassic) ichthyosaur faunas of Central, W and NW Europe appear to be very uniform (Maisch 1999). A palaeobiogeographical separation did probably not take place until the Early Toarcian, when it is quite obvious, not only in ichthyosaurs but also in the plesiosaurs and thalattosuchians (Godefroit 1994; Maisch \& Ansorge 2004). The reconstruction of the palaeobiogeographical history of the Early
Jurassic ichthyosaurs in Europe is affected by the still rare occurrence of Pliensbachian specimens (Hungerbühler \& Sachs 1996; Maisch \& Hungerbühler 1997; McGowan \& Milner 1999; Maisch \& Reisdorf 2006 a, b).

\section{Acknowledgements}

This study would not have been possible without the support of many persons and institutions. H. Hartmann (Pratteln) supplied important stratigraphic information that helped to classify the find and provided his personal collection of ammonites for scientific interpretation. The Saurierkommission Frick and the Sauriermuseum Frick kindly gave permission to examine the specimen. Sincere thanks go to A.T. Matzke (Tübingen) and M. Kröner (Kirchheim/Teck) for interesting discussions on the specimen. W. Gerber (Tübingen) took the photographs. The manuscript benefited from the critical comments of C. Klug (Zürich) and K. Waite (Trondheim). P. Godefroit (Brussels) and M. Sander (Bonn) reviewed the manuscript and kindly provided helpful comments and suggestions. The study was supported by Tonwerke Keller A.G. Frick, who permitted to access to the clay pit where the specimen was found. The following people provided bio- and lithostratigraphic data for this study and fruitful discussions with some of them are gratefully acknowledged: Geologisch-Paläontologischer Arbeitskreis Frick,E. Beher (Heidelberg), M. Benbrahim (Neuchâtel), D. Bieler (Baden-Dättwil), R. Bircher (Stein), G. Bloos (Ludwigsburg), H.R. Bläsi (Bern), T. Bolinger (Olsberg), R. Burkhalter (Bern), W. Etter (Basel), P. Flückiger (Olten), R. Foelix (Aarau), H. Furrer (Zürich), C.L. Graf (Zürich), K. Haldimann (Basel), B. Hostettler (Glovelier), L. Hottinger (Basel), B. Imhof (Trimbach), P. Jordan (Zuchwil), R. Kocher (Aarau), F. König (Oberbözberg), R. Meier (Herznach), C. Obrist (Stein), B. Pabst (Zürich), M. Rümbeli (Frick), B. Rupp (Pratteln), V. Scheuring-Jenni (Basel), I. Stössel (Schaffhausen), P. Vögtli (Diegten), K. Wettstein (Frick), R. Wiss (Basel) and A. Ziems (Basel). This study was financially supported by the Schweizerischer Nationalfonds zur Förderung der wissenschaftlichen Forschung (grants Nos. 20-50484.97, 2000-56640.99 and 2000-064567 to A. Wetzel) and the Freiwillige Akademische Gesellschaft (Basel). All these contributions are gratefully acknowledged.

\section{REFERENCES}

Ayer, J. 2003: Note sur une vertèbre d'Ichthyosaure (Platypterygius sp.) d'âge Aptien trouvée à La Presta (Jura Central; Canton de Neuchâtel, Suisse). Bulletin de la Société Neuchâteloise des sciences Naturelles 126, 121125 .

Berckhemer, F. 1938: Das Gebiß von Leptopterygius platyodon Conyb. Palaeobiologica 6,150-163.

Bloos, G. 1979: Über den Jura am Grossen Haßberg (Unterfranken, N-Bayern) mit Bemerkungen zum Rät. Stuttgarter Beiträge zur Naturkunde Serie B (Geologie und Paläontologie) 44, 53 pp.

Bloos, G., Dietl, G. \& Schweigert, G. 2005: Der Jura Süddeutschlands in der Stratigraphischen Tabelle von Deutschland 2002. Newsletters on Stratigraphy $41,263-277$.

Braun, L. 1920: Geologische Beschreibung von Blatt Frick. Verhandlungen der Naturforschenden Gesellschaft in Basel XXXI, 189-242.

Brinkmann, W. 1998a: Sangiorgiosaurus n.g. - eine neue Mixosaurier-Gattung (Mixosauridae, Ichthyosauria) mit Quetschzähnen aus der Grenzbitumenzone (Mitteltrias) des Monte San Giorgio (Schweiz, Kanton Tessin). Neues Jahrbuch für Geologie und Paläontologie Abhandlungen 207, 125-144.

Brinkmann, W. 1998b: Die Ichthyosaurier (Reptilia) aus der Grenzbitumenzone (Mitteltrias) des Monte San Giorgio (Tessin, Schweiz) - neue Ergebnisse. Vierteljahresschrift der Naturforschenden Gesellschaft in Zürich $143,165-177$.

Brinkmann, W. 2004: Mixosaurier (Reptilia, ichthyosauria) mit Quetschzähnen aus der Grenzbitumenzone (Mitteltrias) des Monte San Giorgio (Schweiz, Kanton Tessin). Schweizerische Paläontologische Abhandlungen 124, 1-86. 
Brok, B. den, Meyer, Ch. A., Thüring, B. \& Favre, P. 2004: Marine reptiles from the Middle Jurassic of Northwestern Switzerland. $2^{\text {nd }}$ EAVP Meeting, 19th-24th of July, 12, Brno.

Buser, H. 1952: Beiträge zur Geologie von Blatt Bözen (Nr. 33) im Schweizerischen Tafeljura unter besonderer Berücksichtigung des Rhät und unteren Lias in den Nachbargebieten. Unpublished PhD Thesis, ETH Zürich, $155 \mathrm{pp}$.

Callaway, J.M. \& Massare, J.A. 1989: Geographic and stratigraphic distribution of the Triassic Ichthyosauria. Neues Jahrbuch für Geologie und Paläontologie Abhandlungen 178,37-58.

Dean, W.T., Donovan, D.T. \& Howarth, M.K.1961:The liassic ammonite zones and subzones of the north-west European province. Bulletin of the British Museum (Natural History) Geology 4, 435-505.

Debrand-Passard, S. 1984: Synthèse géologique du Sud-Est de la France. Volume 2: Atlas. Mémoire du Bureau de Recherche Géologiques et Minières $126,28 \mathrm{pp}$.

Dunham, R.J.1962: Classification of carbonate rocks according to depositional texture. In: Ham, W.E. (Ed.): Classification of Carbonate Rocks. Memoir 1, American Association of Petroleum Geologists, Tulsa, 108-121.

Erni, A. 1910: Das Rhät im schweizerischen Jura. Eclogae geologiae Helvetiae XI, 5-54.

Erni,A. 1926: Zur Rhätfrage im Schweizer Juragebirge. Centralblatt für Mineralogie, Geologie und Paläontologie, Abteilung B, 7, 241-253.

Etzold, A. \& Schweizer, V. 2005: Der Keuper in Baden-Württemberg. In: Deutsche Stratigraphische Kommision (Ed.): Stratigraphie von Deutschland IV, Keuper. Courier Forschungsinstitut Senckenberg 253, 214-258.

Früh, H. 1962: Grabungsbericht zum Saurierfund in Beggingen. Mitteilungen der Naturforschenden Gesellschaft Schaffhausen XXVII, 1-4.

Furrer, H. 1993: Stratigraphie und Facies der Trias/Jura-Grenzschichten in den oberostalpinen Decken Graubündens. PhD Thesis, University Zürich, $99 \mathrm{pp}$.

Galton, P.M. 1986: Prosauropod dinosaurs Plateosaurus (= Gresslyosaurus) (Saurischia: Sauropodomorpha) from the Upper Triassic of Switzerland. Geologica et Palaeontologica 20,167-183.

Godefroit, P. 1992: Présence de Leptopterygius tenuirostris (Reptilia, Ichthyosauria) dans le Lias moyén de Lorraine belge. Bulletin Institut royal des sciences naturelles de Belgique. Sciences de la terre 62, 163 170 .

Godefroit, P. 1993: Les grands ichthyosaures sinémuriens d'Arlon. Bulletin Institut royal des sciences naturelles de Belgique. Sciences de la terre 63, $25-71$.

Godefroit, P. 1994: Les reptiles marins du Toarcien (Jurassique infèrieur) Belgo-luxembourgois. Service géologique de Belgique. Mémoires pour servir à l'Explication des Cartes Géologiques et Minières de la Belgique 39, 1-98.

Godefroit, P. 1996: Un crâne d'Ichthyosaurus communis (Reptilia, Ichthyosauria) du Sinémurien supérieur de Lorrain belge. Bulletin de la Société belge de géologie 104, 77-90.

Gsell, F. 1968: Geologie des Falten- und Tafeljuras zwischen Aare und Wittnau und Betrachtungen zur Tektonik des Ostjura zwischen dem Unteren Hauenstein im W und der Aare im E. PhD Thesis, University Zürich, Offsetdruck Zimmermann, 138 pp.

Hoffmann, K. 1934: Über den unteren Lias der Langenbrückener Senke. I. Jahresberichte und Mitteilungen des Oberrheinischen Geologischen Vereins, Neue Folge 107-131.

Huene, F. von 1916: Beiträge zur Kenntnis der Ichthyosaurier im deutschen Muschelkalk. - Palaeontographica, A, 62,1-68.

Huene, F. von 1922: Die Ichthyosaurier des Lias und ihre Zusammenhänge. Gebr. Borntraeger, Berlin, VI \& 114 pp.

Huene, F. von 1939: Ein ganzes Ichthyosaurier-Skelett aus den westschweizerischen Voralpen. Mitteilungen der Naturforschenden Gesellschaft in Bern, Jahrgang 1939,1-14.

Hugi, J. 2008: The axial and posterior appendicular morphology of the first theropod skeleton (Saurischia, Dinosauria) of Switzerland (Late Triassic; Frick, Canton Aargau). Unpublished Master thesis, University of Zürich, $161 \mathrm{pp}$.
Hungerbühler, A. \& Sachs, S. 1996: Ein großer Ichthyosaurier aus dem Pliensbachium von Bielefeld. - Neue Einblicke in die Ichthyosaurier des Mittleren Lias und das Gebiß von Temnodontosaurus. Bericht des Naturwissenschaftlichen Vereins Bielefeld und Umgegend 37, 15-52.

Jordan, P. 1983: Zur Stratigraphie des Lias zwischen Unterem Hauenstein und Schinznach (Solothurner und Aargauer Faltenjura). Eclogae geologiae Helvetiae 76, 355-379.

Jordan, P., Wetzel, A. \& Reisdorf, A.G. 2008: Jurassic. Swiss Jura Mountains. In: McCann, T. (Ed.): The Geology of Central Europe. Volume 2. Mesozoic and Cenozoic. Geological Society, London, 880-889.

Kelterborn, P. 1944: Beobachtungen im Mont-Terri-Gebiet zwischen Courgenay und Asuel. Eclogae geologiae Helvetiae 37, 207-216.

Kindlimann, R. 1990: Ein Nachweis von Acrodus nobilis AgAssiz aus dem Sinemurien der Tongrube Gruhalde, Frick, Kt. Aargau (Nordschweiz). Eclogae geologiae Helvetiae 83, 829-844.

Klein, M. 1986: Kohlenpetrologische Untersuchungen an Ölschiefern aus dem Sinémurium Südwestdeutschlands. Neues Jahrbuch für Geologie und Paläontologie Monatshefte 1986, 529-540.

Kuhn, E. 1951: Ein Ichthyosauruswirbel aus dem Rhät von Vallon de Novel (Valais). - Eclogae geologiae Helvetiae 44, 426.

Maisch, M.W. 1997: The cranial osteology of Ichthyosaurus intermedius Conybeare, 1822 from the Lias of Great Britain. Stuttgarter Beiträge zur Naturkunde Serie B (Geologie und Paläontologie) 258, 1-27.

Maisch, M.W. 1998: The temporal region of the Middle Jurassic ichthyosaur Ophthalmosaurus - further evidence for the non-diapsid cranial architecture of the Ichthyosauria. Neues Jahrbuch für Geologie und Paläontologie Monatshefte 1998, 401-414.

Maisch, M.W. 1999: Leptonectiden und Temnodontosauriden aus dem AlphaÖlschiefer (Sinemurium) von Baden-Württemberg (SW-Deutschland). Neues Jahrbuch für Geologie und Paläontologie Monatshefte, 1999, 490-512.

Maisch, M.W. \& Ansorge, J. 2004: The Liassic ichthyosaur Stenopterygius cf. S. quadriscissus from the lower Toarcian of Dobbertin (Northeastern Germany) and some considerations on lower Toarcian marine reptile palaeobiogeography. Paläontologische Zeitschrift, 78, 161-171.

Maisch, M.W. \& Hungerbühler,A. 1997: Revision of Temnodontosaurus nuertingensis (v. HUENE, 1931), a large ichthyosaur from the Lower Pliensbachian (Lower Jurassic) of Nürtingen, South Western Germany. Stuttgarter Beiträge zur Naturkunde Serie B (Geologie und Paläontologie) $248,1-11$.

Maisch, M.W. \& Matzke, A.T. 1997a: Mikadocephalus gracilirostris n.g.n. sp., a new ichthyosaur from the Grenzbitumenzone (Anisian-Ladinian) of Monte San Giorgio (Switzerland). Paläontologische Zeitschrift 71, 267289.

Maisch, M.W. \& Matzke, A.T. 1997b: Observations on Triassic ichthyosaurs. Part I. On the structure of the palate and the mode of tooth implantation in Mixosaurus cornalianus (BASSANI, 1886). Neues Jahrbuch für Geologie und Paläontologie Monatshefte 1997, 717-732.

Maisch, M.W. \& Matzke, A.T. 2000a: The Ichthyosauria. Stuttgarter Beiträge zur Naturkunde Serie B (Geologie und Paläontologie) 298,1-159.

Maisch, M.W. \& Matzke, A.T. 2000b: New data on the cranial osteology of Ichthyosaurus communis Conybeare, 1822 (Ichthyosauria, Lower Jurassic). Geologica et Palaeontologica, 34, 137-143.

Maisch, M.W. \& Matzke, A.T. 2005: Observations on Triassic ichthyosaurs. Part XIV:The Middle Triassic mixosaurid Phalarodon major (v. Huene, 1916) from Switzerland and a reconsideration of mixosaurid phylogeny. Neues Jahrbuch für Geologie und Paläontologie Monatshefte, 2005, 597-613.

Maisch, M.W. \& Reisdorf, A.G. 2006a: Evidence for the longest stratigraphic range of a post-Triassic Ichthyosaur: a Leptonectes tenuirostris from the Pliensbachian (Lower Jurassic) of Switzerland. Geobios, 39, 491-505.

Maisch, M.W. \& Reisdorf, A.G. 2006b: Erratum to the article "Evidence for the longest stratigraphic range of a post-Triassic Ichthyosaur: a Leptonectes tenuirostris from the Pliensbachian (Lower Jurassic) of Switzerland", Geobios 39, 491-505. Geobios, 39, 743-746.

Maisch, M.W., Matzke, A.T. \& Brinkmann,W. 2006: The otic capsule of the Middle Triassic ichthyosaur Mixosaurus from Monte San Giorgo (Swit-

626 M.W. Maisch et al. 
zerland): new evidence on the braincase structure of basal ichthyosaurs. Eclogae geologicae helvetiae 99, 205-210.

McGowan, C. 1973: The cranial morphology of the Lower Liassic latipinnate ichthyosaurs of England. Bulletin of the British Museum (Natural History) Geology 24, 1-109.

McGowan, C. 1974: A revision of the latipinnate ichthyosaurs of the Lower Jurassic of England (Reptilia: Ichthyosauria). Life Sciences Contributions, Royal Ontario Museum 100, 1-30.

McGowan, C. \& Milner, A.C. 1999: A new Pliensbachian ichthyosaur from Dorset, England. Palaeontology, 42, 761-768.

Mettraux, M. \& Mohr, B. 1989: Stratigraphy of the Triassic/Jurassic boundary in the "Préalpes Médianes" nappe: Facies and palynology. Eclogae geologiae Helvetiae 82, 743-763.

Meyer, C.A. \& Furrer, H. 1995: Taphonomie und paläoökologische Rekonstruktionen: Beispiele aus dem Mesozoikum des Jura. Eclogae geologiae Helvetiae 88, 711-720.

Moesch, C. 1857: Das Flözgebirge im Kanton Aargau. Neue Denkschrift der allgemeinen schweizerischen Gesellschaft für die ges. Naturwissenschaften, XV, 1857, 80 pp.

Motani, R. 1999: Phylogeny of the Ichthyopterygia. Journal of Vertebrate Paleontology 19, 473-496.

Müller,W.H., Huber, M., Isler, A. \& Kleboth, P. 1984: Erläuterungen zur Geologischen Spezialkarte Nr. 121 der zentralen Nordschweiz 1: 100'000 mit angrenzenden Gebieten von Baden-Württemberg. Nationale Genossenschaft für die Lagerung radioaktiver Abfälle (NAGRA) und Schweizerische Geologische Kommission, Baden, 234 pp.

Peters, T.J. 1964: Tonmineralogische Untersuchungen an einem Keuper-LiasProfil im Schweizer Jura (Frick). Schweizerische Mineralogische und Petrographische Mitteilungen 44, 1-30.

Peyer, B. \& Koechlin, E. 1934: Ein Saurierwirbel aus dem Terrain à chailles von Grellingen (Berner Jura). Verhandlungen der Naturforschenden Gesellschaft in Basel XLV, 68-77.

Reiff, W. 1935: Saurierreste des Lias $\alpha$ der Langenbrückener Senke. Zentralblatt für Mineralogie, Geologie und Paläontologie 1935, 227-253.

Sander, P.M. 1989: The large ichthyosaur Cymbospondylus buchseri sp.nov. from the Middle Triassic of Monte San Giorgio (Switzerland) with a survey of the genus in Europe. Journal of Vertebrate Paleontology 9, 163-173.

Sander, P.M. 1990: Keuper und Lias der Tongrube Frick. In: Weidert, W.K. (Ed.): Klassische Fundstellen der Paläontologie, Band II, Goldschneck, Korb, 89-96.
Sander, P.M. 1992: The Norian Plateosaurus bonebeds of central Europe and their taphonomy. Palaeogeography, Palaeoclimatology, Palaeoecology, 9, 255-299.

Schlatter, R. 1975: Geologische und paläontologische Untersuchungen im unteren Lias des Donau-Rheinzuges und im Kanton Aargau. Unpublished MSc. thesis, ETH Zürich, 171 pp.

Schmid, D.U., Leinfelder, R.R. \& Schweigert, G. 2008: Jurassic. Southern Germany. In: McCann, T. (Ed.): The Geology of Central Europe. Volume 2. Mesozoic and Cenozoic. Geological Society, London, 864-873.

Sollas, W.J. 1916: The skull of Ichthyosaurus studied in serial sections. Philosophical Transactions of the Royal Society of London B 208, 63-126.

Stoll-Steffan, M.-L. 1987: Sedimentpetrographische Untersuchungen der Lias alpha- und Rhätsandsteine im westlichen Deutschen Alpenvorland. Bochumer geologische und geotechnische Arbeiten, 24, 188 pp.

Urlichs, M. 1977: The Lower Jurassic in Southwestern Germany. Stuttgarter Beiträge zur Naturkunde Serie B (Geologie und Paläontologie) 24, $1-41$.

Walliser, O.H. 1956a: Chronologie des Lias alpha ${ }_{3}$ zwischen Fildern und Klettgau (Arietenschichten, SW-Deutschland). Neues Jahrbuch für Geologie und Paläontologie Abhandlungen B 103, 181-222.

Walliser, O.H. 1956b: Stratigraphie des Lias alpha ${ }_{3}$ zwischen Fildern und Klettgau (Arietenschichten, SW-Deutschland). Neues Jahrbuch für Geologie und Paläontologie Abhandlungen B, 103, 281-311.

Weidmann, M. 1981: Un ichthyosaure dans le Lias supérieur des Préalpes médianes vaudoises. Bulletin de la Société vaudoise des Sciences naturelles, $75,165-170$.

Wetzel, A. \& Reisdorf, A.G. 2007: Ichnofabrics elucidate the accumulation history of a condensed interval containing a vertically emplaced ichthyosaur skull. In: Bromley, R.G. et al. (Eds.): Ichnology at the Crossroads: A Multidimensional Approach to the Science of Organism-Substrate Interactions. SEPM Special Publications 88, 239-249.

Wetzel, A. \& Allia, V. 2000: The significance of hiatus beds in shallow-water mudstone: an examble from Middle Jurassic of Switzerland. Journal of Sedimentary Research 70,170-180.

Manuscript received March 7, 2008

Revision accepted October 26, 2008

Published Online first: December 2, 2008

Editorial handling: Michael J. Benton \& J.-P. Billon-Bruyat 